\title{
Construction and Analysis of Binary Vectors for Co-Overexpression, Tissue- or Development-Specific Expression and Stress-Inducible Expression in Plant
}

\author{
Young-Mi Lee, Hee-Yeon Park, Dong-Hyuk Woo, Hye-Yeon Seok, Sun-Young Lee ${ }^{1}$ and Yong-Hwan Moon* \\ Department of Molecular Biology, Pusan National University, Busan 609-735, Korea \\ ${ }^{1}$ Ulsan University Hospital Biomedical Research Center, University of Ulsan, Ulsan 680-749, Korea
}

Received July 26, 2010 / Accepted September 7, 2010

\begin{abstract}
In this study, we constructed various kinds of binary vectors with the pPZP backbone for co-overexpression, tissue- or development-specific expression and stress-inducible expression, and validated them for ectopic expression of target genes. Using a modified CaMV $35 \mathrm{~S}$ promoter, a binary vector was generated for co-overexpression of two different genes and was confirmed to be efficient for overexpressing two different target genes at the same time and place. Binary vectors containing At2S3, KNAT1 or LFY promoters were constructed for tissue-specific or development-specific gene expression, and the binary vectors were suited for embryo/young seedling stage-, shoot apical meristem- or leaf primordia-specific expressions. Furthermore, the binary vectors containing RD29A or AtNCED3 promoters were validated as suitable vectors for gene expression induced by abiotic stresses such as high salt, ABA, MV and low temperature. Taken together, the binary vectors constructed in this study would be very useful for analyzing the biological functions of target genes and molecular mechanisms through ectopic expression.
\end{abstract}

Key words : Binary vector, co-overexpression, tissue-specific, development-specific, stress-inducible

\section{Introduction}

In plants, biological functions of target genes can be analyzed by the qualitative and quantitative changes of mRNAs, proteins and metabolites in transgenic plants, where target gene is ectopically expressed [12]. Various binary vectors have been developed to overexpress target genes in plants. The promoter is particularly important in the overexpression binary vector. The cauliflower mosaic virus (CaMV) 355 promoter and plant-derived ubiquitin (UBQ) promoters have been widely used for the overexpression of target genes in plants $[8,13,16]$. CaMV $35 S$ promoter is about 350 bp long and consists of domain A $(-90$ to +8$)$ and B (-343 to -91$)$. A modified CaMV 355 promoter, in which -90 to -47 of domain A has been removed, is more effective than a full-length promoter for the overexpression of target genes [18]. Arabidopsis $U B Q$ gene family consists of 14 members and many of the $U B Q$ genes are constitutively expressed in most organs $[4,9,23]$. Especially, the promoters of $U B Q 3$ and UBQ10 showed constitutive activities in most organs $[18,26]$.

It is often necessary to generate the transgenic plants that overexpress two different genes at the same time and place.

*Corresponding author

Tel : +82-51-510-2592, Fax : +82-51-513-9258

E-mail : moonyh@pusan.ac.kr
For example, it is very useful to check the cellular co-localization of two different proteins encoded by different genes each other or to study the phenotypes of the double-transgenic plants which overexpress two different genes together, etc. The method of co-overexpression has been developed such as cross-fertilization and two transformations [20]. However, these are difficult to select the transgenic plants that overexpress both genes and have low efficiency. To ease the generation of co-overexpression transgenic plants, we developed co-overexpression vector and tested for its efficiency and application.

Although the overexpression of target genes is very useful for the study of gain-of-function genetics, it sometimes interrupts the normal growth of plants and even causes embryonic lethality. To solve these problems, other kinds of ectopic expression binary vectors have been developed for tissue-specific, development-specific and stress-inducible expressions $[3,22,28]$. Occasionally, it is necessary to limit the expression of target genes in stress conditions for the functional studies and applications of stress-related genes to generate stress-tolerant plants, etc.

Agrobacterium-mediated transformation has been widely used in the plant transformation and binary vectors are essential in the method [2]. Most of the old binary vectors such as BIN19, pGA482 and pGA492 are large, unstable in 
Agrobacterium, have not been sequenced, lack convenient restriction sites in multiple cloning sites (MCS) and have low replicative copy number in bacteria $[1,2]$. To overcome these disadvantages, new binary vectors such as pPZP, pRCS2-ocs and pMSP have been developed [17]. One of them, pPZP, is versatile, relatively small and stable in Agrobacterium even if grown under non-selective conditions [6], has high replicative copy number in E. coli (about 200 copies per cell) and 3-5 copies in Agrobacterium and fully sequenced [11].

In this study, various binary vectors with pPZP backbone were constructed and tested for ectopic expression of target genes. For ectopic expression, binary vectors were generated for co-overexpression, tissue-specific, development-specific and stress-inducible expression. Our results indicate that binary vectors for ectopic expression constructed in this study would be beneficial to investigate the biological functions of target genes.

\section{Materials and Methods}

\section{Plasmid constructions}

In order to generate promoter analysis vectors, promoters were amplified by PCR. Primers used for the PCR reaction were as following Table 1 . Amplified promoters were cloned into pFGL75 (pPZP211-Tnos) and pFGL539 (pPZP211- $\beta$ -glucuronidase (GUS)-Tnos). Information of the promoter regions can be found at NCBI (http://www.ncbi.nlm.nih.gov/) and TAIR (http://www.arabidopsis.org/).

\section{Plant materials and growth conditions}

The Arabidopsis thaliana genotype used in all experiments was Columbia. Arabidopsis seeds were surface-sterilized in 70\% EtOH for $1 \mathrm{~min}$, in 1/10-diluted commercial Clorox (final $0.4 \% \mathrm{NaOCl}$ ) for $10 \mathrm{~min}$, and were washed four times with distilled water. Surface-sterilized Arabidopsis seeds were placed in the dark condition for 2 days at $4^{\circ} \mathrm{C}$ and then germinated on agar plates containing half-strength of MS salts [21], vitamins, $1.5 \%$ sucrose and $0.7 \%$ agar. Plates were placed under short-day (SD) conditions $(8 \mathrm{hr}$ of light $/ 16 \mathrm{hr}$ of dark) at $22^{\circ} \mathrm{C}$. Ten- to twelve-day-old seedlings were transplanted to soil and grown under long-day (LD) conditions (16 hr of light/8 hr of dark) at $22^{\circ} \mathrm{C}$.

\section{Plant transformation and selection of transgenic plants}

Constructs for promoter analysis of Arabidopsis were transformed into Agrobacterium tumefaciens strain, GV3101 (pMP90), by freeze-thaw method [33]. Then, Agrobacterium was transformed into Arabidopsis wild-type plants by

Table 1. List of primers used in PCR

\begin{tabular}{|c|c|c|c|}
\hline Amplification targets & Orientation & Sequences & Purposes \\
\hline CaMV $35 S$ promoter B domain & Forward & 5'-GGGAAGCTTTGAGACTTTTCAACAAAG-3' & Cloning \\
\hline CaMV $35 S$ promoter B domain & Reverse & 5'-GGGGAATTCTATCACATCAATCCACTT-3' & Cloning \\
\hline CaMV $35 S$ promoter core & Forward & 5'-CAAGAATTCGCAAGACCCTTCCTCTAT-3' & Cloning \\
\hline CaMV $35 S$ promoter core & Reverse & 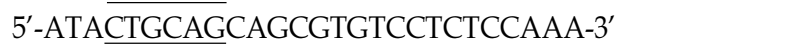 & Cloning \\
\hline At2S3 promoter & Forward & 5'-CCCAAGCTTGAAACCAAATTAACATAG-3' & Cloning \\
\hline At2S3 promoter & Reverse & 5'-CCCCTGCAGGTTTTGCTATTTGTGTATGTT-3' & Cloning \\
\hline KNAT1 promoter & Forward & 5'-CCCAAGCTTGATCTAGAGCCCTAGGAT-3' & Cloning \\
\hline KNAT1 promoter & Reverse & 5'-CСССТGCAGACCCAGATGAGTAAAGATTTGAG-3' & Cloning \\
\hline LFY promoter & Forward & 5'-GCGCTGCAGTTTTTCGCAAAGGAAAGT-3' & Cloning \\
\hline LFY promoter & Reverse & 5'-GCGCCCGGGATAATCTATTTTTCTCTC-3' & Cloning \\
\hline RD29A promoter & Forward & 5'-GCGAAGCTTGGTGAATTAAGAGGAGAGAGGAGG-3' & Cloning \\
\hline$R D 29 A$ promoter & Reverse & 5'-ACACTGCAGTGAGTAAAACAGAGGAGGGTCTCAC-3' & Cloning \\
\hline AtNCED3 promoter & Forward & 5'-CGCGTCGACATGTACAAAAACACCTATAA-3' & Cloning \\
\hline AtNCED3 promoter & Reverse & 5'-GCGCCCGGGTTTTCAAGTGTGTTCAATCA-3' & Cloning \\
\hline GAPC & Forward & 5'-CCA $\overline{\text { GCTCTTAACGGAAAGTTG-3' }}$ & RT-PCR \\
\hline GAPC & Reverse & 5'-CCTGTTGTCGCCAACGAAGTC-3' & RT-PCR \\
\hline GAPC & Forward & 5'-GTGTCCCAACCGTTGATGTC-3' & qRT-PCR \\
\hline GAPC & Reverse & 5'-TCCCTTGAGTTTGCCTTCGG-3' & qRT-PCR \\
\hline RD29A & Forward & 5'-GAAACAGAGTCTGCCGTGAC-3' & RT-PCR \\
\hline RD29A & Reverse & 5'-TGCTGCCTTCTCGGTAGAGA-3' & RT-PCR \\
\hline GUS & Forward & 5'-CTTACAGGCGATTAAAGAGC-3' & RT-PCR/qRT-PCR \\
\hline GUS & Reverse & 5'-ATCGGCTGATGCAGTTTCTC-3' & RT-PCR \\
\hline GUS & Reverse & 5'-GTTCGTTGGCAATACTCCAC-3' & qRT-PCR \\
\hline
\end{tabular}


floral-dipping method [5]. Arabidopsis transgenic plants were selected from a medium containing $25 \mathrm{mg} / 1$ kanamycin.

\section{Treatments of $\mathrm{NaCl}, \mathrm{ABA}, \mathrm{MV}$ and low temperature}

7-day-old GUS-expressing transgenic plants grown on MS agar media were treated with $\mathrm{NaCl}$, abscisic acid (ABA), methyl viologen (MV) and low temperature for GUS assay and RT-PCR. For NaCl, ABA and MV treatments, 7-day-old GUS-expressing transgenic seedlings grown on MS agar media were transferred to filter paper saturated with $300 \mathrm{mM}$ $\mathrm{NaCl}, 100 \mu \mathrm{M}$ ABA or $10 \mu \mathrm{M} \mathrm{MV}$, respectively, and kept for 0 or $5 \mathrm{hr}$. For low temperature, 7-day-old GUS-expressing transgenic seedlings grown on MS agar media were transferred to filter paper saturated with liquid MS media and placed at $4^{\circ} \mathrm{C}$ for $5 \mathrm{hr}$.

\section{Histochemical GUS assay}

The promoter-GUS transgenic plants, grown on MS agar media, were collected and used for histochemical detection of GUS expression. For general detection of GUS expression patterns in plants, samples were vacuum-infiltrated in $1 \mathrm{mg} / \mathrm{ml} \mathrm{X-gluc,} 5 \mathrm{mM}$ potassium ferricyanide, $5 \mathrm{mM}$ potassium ferrocyanide, $0.07 \%$ Triton $\mathrm{X}-100$ and 50 $\mathrm{mM}$ sodium phosphate buffer $(\mathrm{pH} 7.0)$ for $10 \mathrm{~min}$ and stained at $37^{\circ} \mathrm{C}$ for $6 \mathrm{hr}$. Samples were rinsed with $50 \mathrm{mM}$ sodium phosphate and fixed with 9 parts of $95 \%$ ethanol and 1 part of glacial acetic acid overnight at room temperature. Solution was changed to $70 \%$ ethanol and samples were stored at $4^{\circ} \mathrm{C}$.

\section{Quantitative GUS assay}

Quantitative GUS assays were performed according to Gallagher [7]. $100 \mathrm{mg}$ whole seedlings were ground in 300 $\mu l$ extraction buffer $\left(50 \mathrm{mM} \mathrm{NaPO}_{4}, \mathrm{pH}\right.$ 7.0, 1 mM EDTA, $10 \mathrm{mM} \beta$-mercaptoethanol, $0.1 \%$ Triton X-100 and $0.1 \%$ sodium lauryl sarcosine) in a microcentrifuge tube. Cell debris was removed from the homogenates by centrifugation at $12,000 \mathrm{rpm}$ for $15 \mathrm{~min}$. $50 \mu \mathrm{L}$ of the homogenates were mixed with $450 \mu \mathrm{l} \mathrm{GUS}$ assay buffer (2 $\mathrm{mM}$ 4-methylumbelliferylD-glucuronide in extraction buffer) and incubated at $37^{\circ} \mathrm{C}$ for $1 \mathrm{hr}$. Aliquots of $200 \mu \mathrm{l}$ were taken and the reaction was stopped by adding $800 \mu \mathrm{l}$ stop buffer $\left(0.2 \mathrm{M} \mathrm{Na}_{2} \mathrm{CO}_{3}\right)$. Fluorescent products were quantified with a fluorometer. Fluorescence of 4-methylumbelliferone (4MU) was measured with excitation at $365 \mathrm{~nm}$ and emission at $455 \mathrm{~nm}$.

\section{RNA isolation}

Total RNA was isolated using Tri Reagent (Molecular Research Center, USA). $5 \mu \mathrm{g}$ of total RNA was pretreated with RNase-free DNase I (Promega, USA) and reverse-transcribed in total volume of $50 \mu \mathrm{l}$ containing 50 pmole oligo-dT, $1 \mathrm{mM}$ dNTP and 200 units of molony murine leukemia virus (M-MLV) reverse transcriptase (Promega, USA).

\section{Semi-quantitative RT-PCR and quantitative RT-PCR}

Semi-quantitative RT-PCR was performed in $50 \mu \mathrm{l} \mathrm{sol-}$ ution containing $1 \mu \mathrm{l}$ RT product, 25 pmole gene specific primers, $0.5 \mathrm{mM}$ dNTP, 1 unit of F-taq DNA polymerase (Solgent, Korea) and $5 \mu \mathrm{l} \mathrm{10x}$ reaction buffer. PCR cycles of 27 to 33 were performed for RD29A and GUS, and 24 to 27 cycles for GAPc. The number of PCR cycles chosen was shown to be in the linear range of the amplification reaction (data not shown). GAPC as an internal control was amplified. The reaction included an initial $5 \mathrm{~min}$ denaturation at $94^{\circ} \mathrm{C}$, followed by repeated cycles at $94^{\circ} \mathrm{C}$ for $45 \mathrm{sec}$, at $56^{\circ} \mathrm{C}$ for $45 \mathrm{sec}$, at $72^{\circ} \mathrm{C}$ for $45 \mathrm{sec}$ and final $10 \mathrm{~min}$ at $72^{\circ} \mathrm{C}$. Primers used for the PCR reaction were as following Table 1.

Diluted cDNA was used as template for quantitative RT-PCR using a StepOne real-time PCR system (Applied Biosystems, USA). Each $20 \mu \mathrm{l}$ reaction mix contained $10 \mu \mathrm{l}$ 2x POWER SYBR Green PCR Master mix and $0.5 \mu \mathrm{M}$ gene specific primers. Real-time DNA amplification was analyzed using the software, StepOne (version 2.1). The Ct (cycle at the threshold) value is set constant throughout the study and corresponds to the log linear range of PCR amplification. The normalized amount of target reflects the relative amount of target transcripts with respect to the endogenous reference gene GAPc. The reaction included an initial $10 \mathrm{~min}$ denaturation at $95^{\circ} \mathrm{C}$, followed by repeated cycles at $95^{\circ} \mathrm{C}$ for $15 \mathrm{sec}, 56^{\circ} \mathrm{C}$ for $15 \mathrm{sec}$ and $72^{\circ} \mathrm{C}$ for $15 \mathrm{sec}$. Primers used for the PCR reaction were as following Table 1.

\section{Transient gene expression in Arabidopsis protoplasts}

To investigate the cellular localization of target genes in Arabidopsis protoplasts, polyethylene glycol (PEG)-mediated protoplast transformations were performed according to the method described by Sheen [30]. Protoplasts were transformed with $20 \mu \mathrm{g}$ of plasmid DNA. Transformed protoplasts were incubated at $22^{\circ} \mathrm{C}$ in the dark for $24 \mathrm{hr}$ to allow the accumulation of the synthetic green fluorescent protein (sGFP) and red fluorescent protein (RFP) fusion proteins. sGFP and RFP signals were detected by fluorescence microscopy. 


\section{Results}

\section{Co-overexpression binary vectors}

CaMV 35S promoter has been widely used to overexpress target genes in plants. A modified CaMV $35 S$ promoter, combination of domain $\mathrm{B}$ and minimal promoter, was used for the co-overexpression of target genes in this study [18]. To overexpress two different genes concomitantly, a binary vector containing two modified CaMV 355 promoters was constructed and named as pFGL1217 (Fig. 1A). To confirm that the construct is able to overexpress two different target genes properly, RFP and sGFP reporter genes were ex-

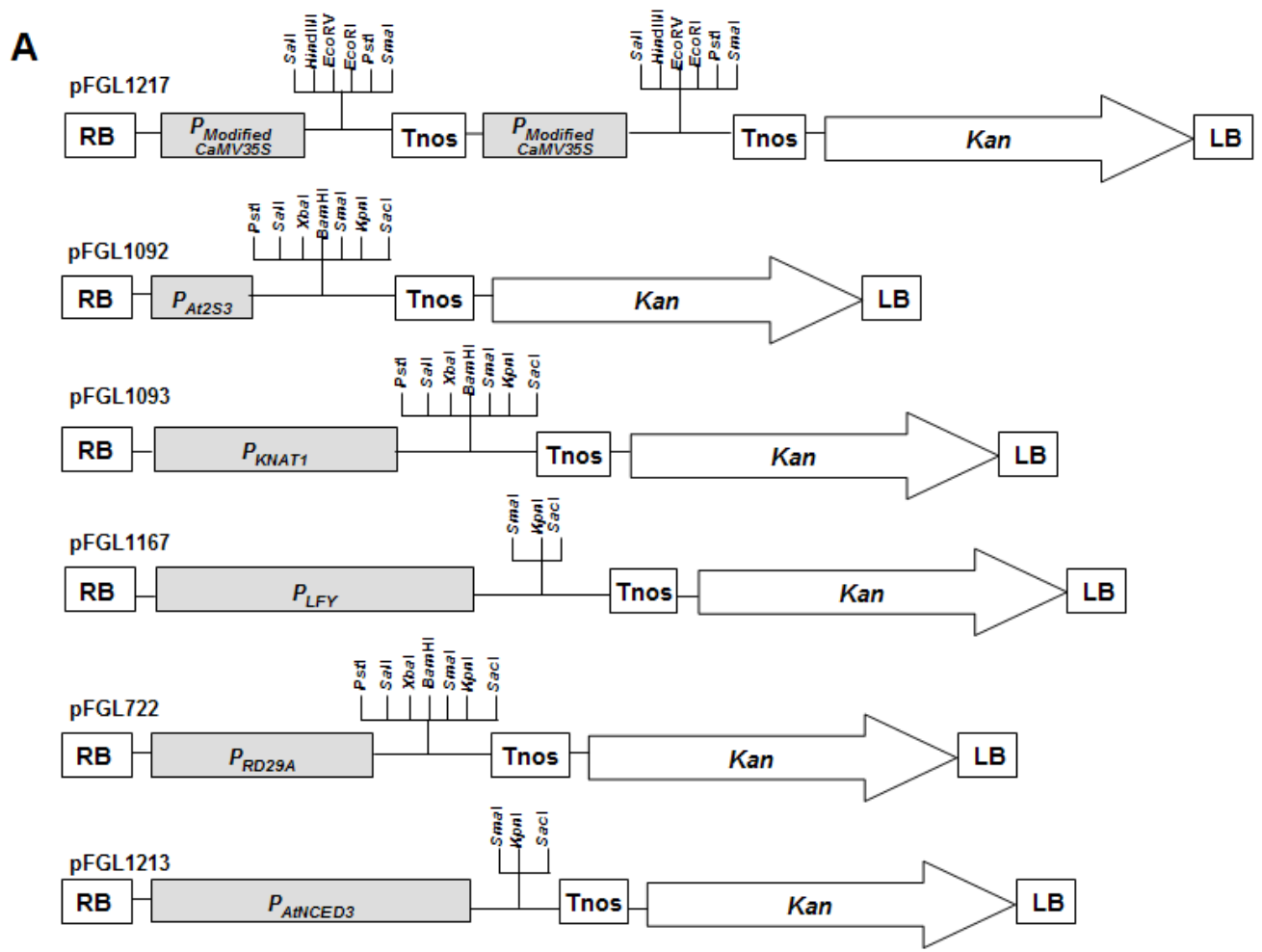

B

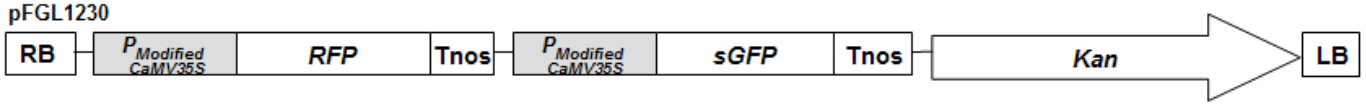

\begin{tabular}{|l|l|l|l|l|}
\hline RFGL1091 & GUS & Tnos \\
\hline At2S3 & Gan \\
\hline
\end{tabular}

\begin{tabular}{|l|l|l|l|l|}
\hline RB & GUS & TnOS \\
\hline
\end{tabular}

\begin{tabular}{|l|l|l|l|l|}
\hline RB & GUS & Tnos \\
\hline
\end{tabular}

\begin{tabular}{|l|l|l|l|l|l|}
\hline RB & GEG \\
\hline
\end{tabular}

\begin{tabular}{|l|l|l|l|l|}
\hline RB & GUS & Tnos \\
\hline AtCED3 & Gan \\
\hline
\end{tabular}

Fig. 1. Schematic maps of binary vectors constructed in this study. (A) T-DNA regions of pFGL1217, pFGL1092, pFGL1093, pFGL1167, pFGL722 and pFGL1213. (B) Promoter::reporter gene:Tnos regions of pFGL1230, pFGL1091, pFGL1095, pFGL1168, pFGL723 and pFGL1103. RB: right border, LB: left border. 
pressed under the control of each modified CaMV 355 promoter (Fig. 1B). Using the RFP and sGFP signal, it was confirmed that the RFP and $s G F P$ were overexpressed in the cytoplasm and the nucleus of the Arabidopsis protoplasts containing modified CaMV 35S::RFP:modified CaMV 35S::sGFP (Fig. 2).
Tissue- or development-specific expression binary vectors

For the tissue-specific or development-specific expression, the promoters of Arabidopsis thaliana 2S ALBUMIN 3 (At2S3), KNOTTED-LIKE FROM ARABIDOPSIS THALIANA 1 (KNAT1) and LEAFY (LFY) were used. At2S3 is expressed

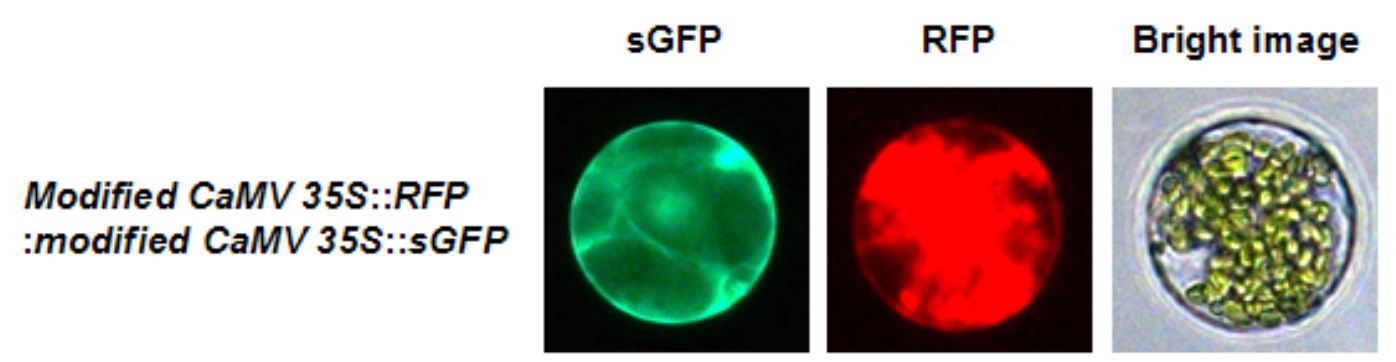

Fig. 2. Transient expression assay of co-overexpression vector. sGFP and RFP were detected in the same Arabidopsis protoplast transformed by pFGL1230.

A

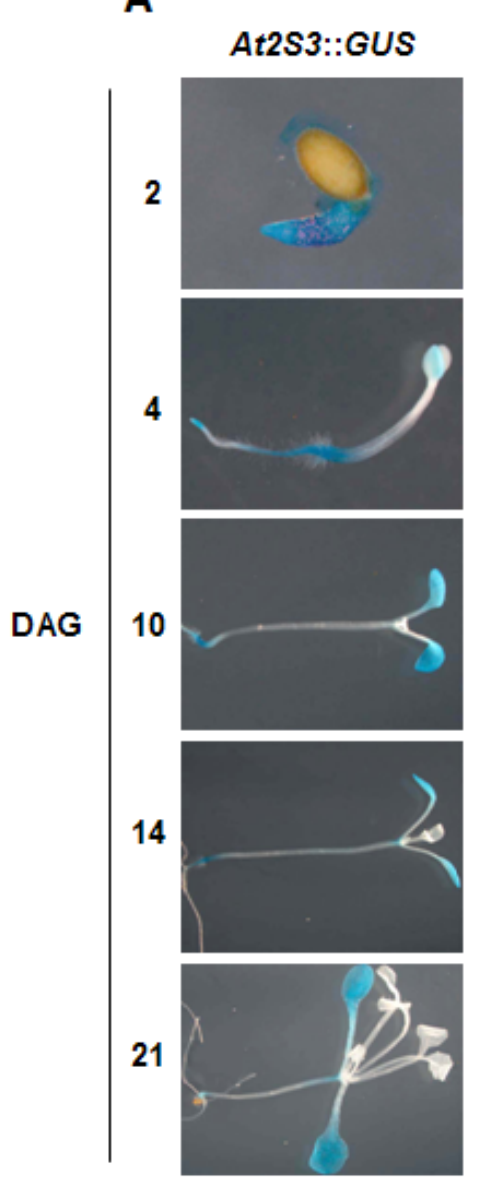

B

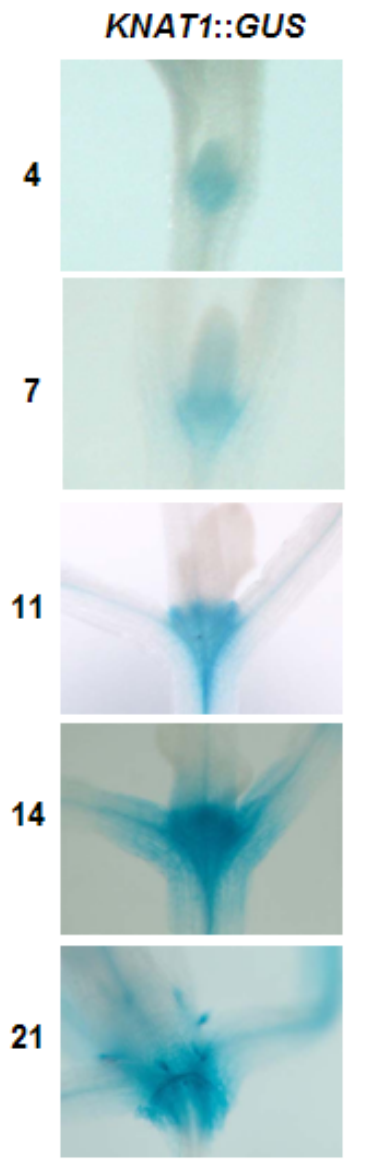

C

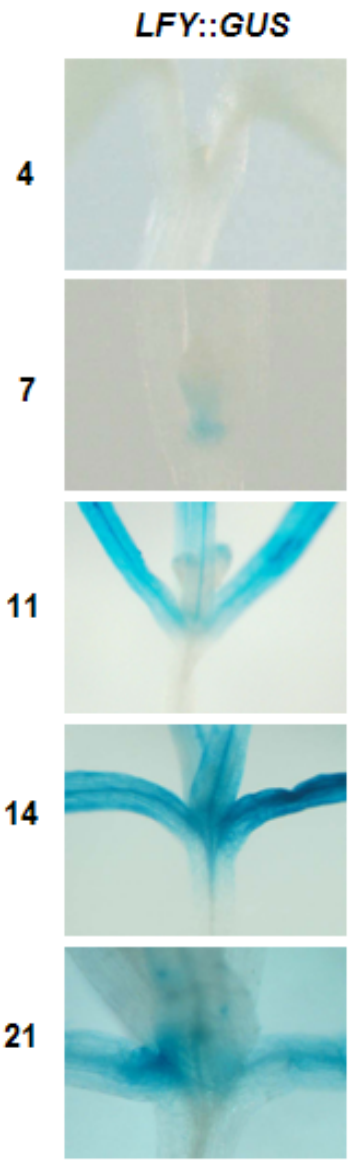

Fig. 3. Analysis of GUS activities in transgenic plants carrying tissue-specific and development-specific promoter::GUS constructs. (A) GUS activities in 2-, 4-, 10-, 14- and 21-day-old seedlings containing At2S3::GUS grown under SD condition. (B) GUS activities in 4-, 7-, 11-, 14- and 21-day-old seedlings containing KNAT1::GUS grown under SD condition. (C) GUS activities in 4-, 7-, 11-, 14- and 21-day-old seedlings containing LFY::GUS grown under LD condition. 
in the early developmental stage $[10,24]$. KNAT1 is expressed in the shoot apical meristem and the stem but not in the leaves and the roots [19], similar to the expression of many $k n 1$-like homeobox genes of maize [15]. LFY is expressed in the leaf primordia but not in the shoot apical meristem $[25,29]$.

Each of the three promoters was cloned into pFGL75 (pPZP211-Tnos). Binary vectors containing At2S3, KNAT1 and LFY promoters were named as pFGL1092, pFGL1093 and pFGL1167, respectively (Fig. 1A). In order to confirm that the constructs were able to express target genes properly in plants, GUS reporter gene was expressed under the control of each promoter (Fig. 1B). With At2S3::GUS plants,
GUS expression was observed in the cotyledons but not in the shoot apex and leaves (Fig. 3A). From 2 days after germination (DAG) to $21 \mathrm{DAG}$, GUS activity was observed in the cotyledons and gradually decreased in the roots. With the KNAT1 promoter, GUS activity was found in the shoot apical meristem from 4 DAG to 21 DAG (Fig. 3B). On the other hand, the LFY::GUS plants showed GUS activity in leaf primordia from early developmental stage of seedlings (Fig. 3C).

\section{Stress-inducible expression binary vectors}

For stress-inducible expression, promoters of Responsive to desiccation 29A (RD29A) and Arabidopsis thaliana 9-cis-epoxycarotenoid dioxygenase 3 (AtNCED3) were used to construct
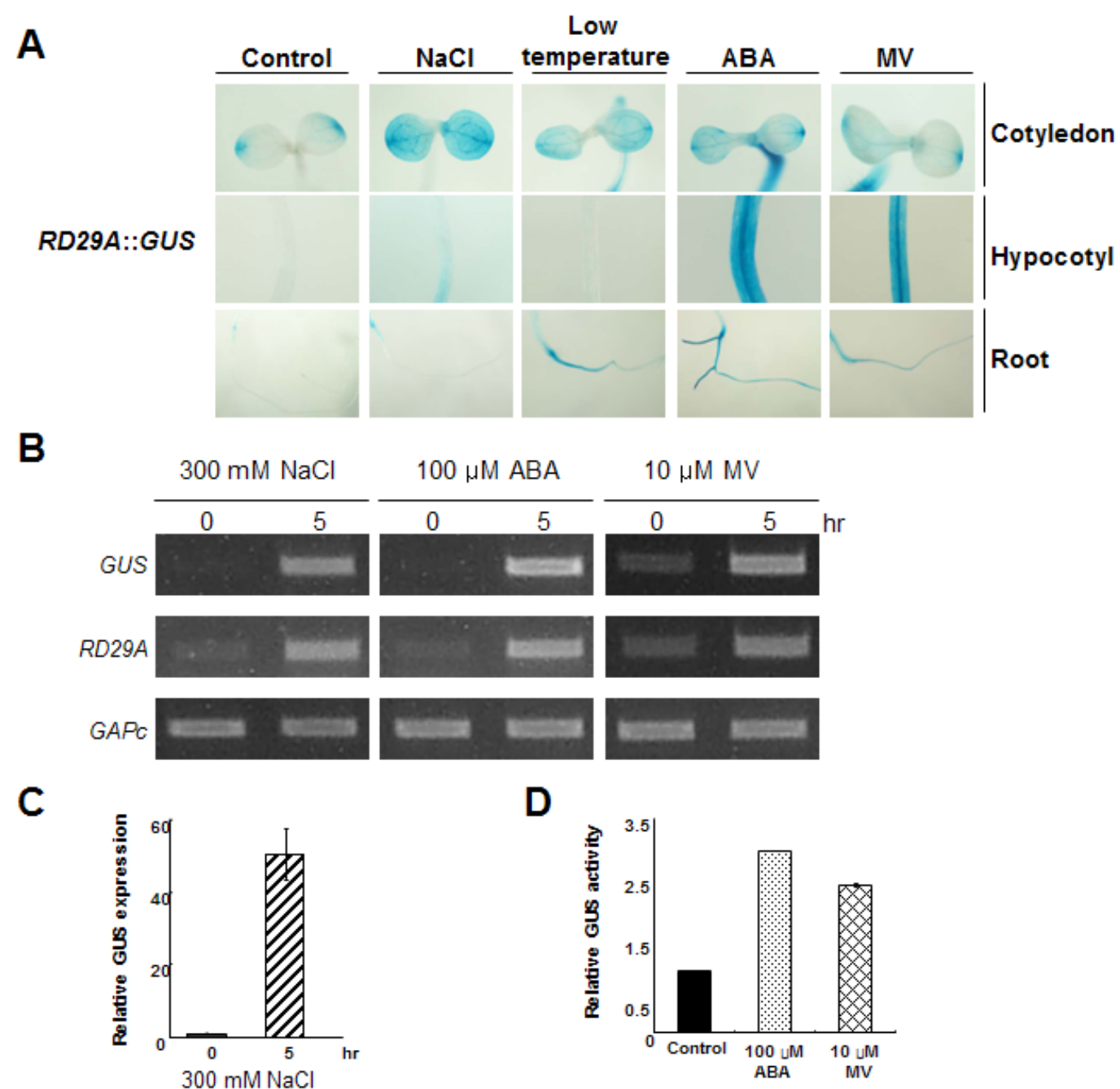

Fig. 4. Analysis of RD29A promoter activities in RD29A::GUS-expressing transgenic plants under abiotic stress. (A) GUS activities in 7-day-old seedlings under $300 \mathrm{mM} \mathrm{NaCl}$, low temperature $\left(4^{\circ} \mathrm{C}\right), 100 \mu \mathrm{M} \mathrm{ABA}$ or $10 \mu \mathrm{M} \mathrm{MV}$ treatments for $5 \mathrm{hr}$. (B) Semi-quantitative RT-PCR analysis was performed using seedlings treated with $300 \mathrm{mM} \mathrm{NaCl}, 100 \mu \mathrm{M}$ ABA or $10 \mu \mathrm{M}$ MV. GAPc was used as an internal control. (C) Quantitative RT-PCR analysis was performed for seedlings treated with 300 $\mathrm{mM} \mathrm{NaCl}$. (D) Quantitative GUS assay was performed using seedlings treated with $100 \mu \mathrm{M}$ ABA or $10 \mu \mathrm{M}$ MV. 
the binary vectors. The expression of $R D 29 A$ is induced by dehydration, high salinity and low temperature [31,32,35] whereas AtNCED3 expression is induced by osmotic stress [34]. The promoter of RD29A or AtNCED3 was cloned into pFGL75 (pPZP211-Tnos). The binary vectors containing RD29A and AtNCED3 promoters were named as pFGL722 and pFGL1213, respectively (Fig. 1A).

In order to confirm that the constructs are able to induce the target genes properly in plants, GUS reporter gene was expressed under the control of each promoter (Fig. 1B). GUS activities were analyzed in the RD29A::GUS and AtNCED3::GUS plants under various abiotic stress treatments. GUS activities were increased in the cotyledons of the RD29A::GUS plants after $\mathrm{NaCl}, \mathrm{ABA}, \mathrm{MV}$ and low temperature treatments (Fig. $4 \mathrm{~A}$ ). $\mathrm{ABA}$ and MV treatments also induced GUS expression in the hypocotyls and roots as well as the cotyledons. With the RD29A promoter, GUS expression was 50-fold, 3-fold and 2.5-fold higher than control after $\mathrm{NaCl}, \mathrm{ABA}$ and $\mathrm{MV}$ treatments, respectively (Fig. $4 \mathrm{~B}$ and $4 \mathrm{C}$ ). Using GUS assay and RT-PCR analysis, it was confirmed that GUS expression was induced by $\mathrm{NaCl}, \mathrm{ABA}$ and MV treatments in the cotyledons of the AtNCED3::GUS plants (Fig. 5A and 5B).

\section{Discussion}

In this study, co-overexpression, tissue-/development- specific expression and stress-inducible expression binary vectors were generated for the ectopic expression of target genes.

It is often necessary to overexpress two different genes in the same transgenic plant. pFGL1217 was constructed to co-overexpress two different genes at same time and place under the control of two modified CaMV 355 promoters. Transient expression assay using Arabidopsis protoplast showed that this binary vector would be efficient to overexpress two different genes together (Fig. 2). These results suggest that the method of generating transgenic plants overexpressing two different genes using this vector might reduce cost and time compared with existing methods such as cross-fertilization and two transformations which are difficult to select the transgenic plants that overexpress both genes.

For the tissue-specific or development-specific expression of target genes, promoters of At2S3, KNAT1 and LFY genes were used. With At2S3 promoter, GUS activity was found in the cotyledons and radicle of seedlings at 2 to 21 DAG but absent in the shoot apex and leaves (Fig. 3A). With KNAT1 promoter, GUS activity was observed in the shoot apical meristem of seedlings but not detected in the leaf primordial (Fig. 3B). On the other hand, LFY::GUS activity was found in the leaf primordia of seedlings but absent in the shoot apical meristem (Fig. 3C). These development- or tis-

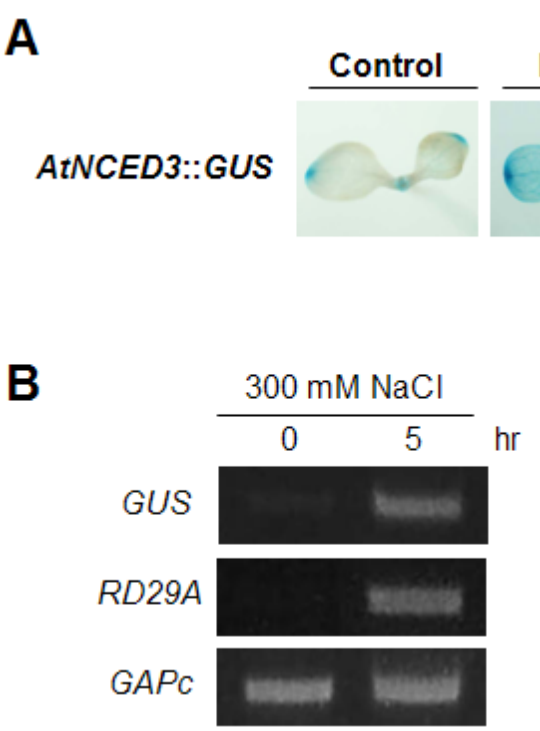

Fig. 5. Analysis of AtNCED3 promoter activities in AtNCED3::GUS-expressing transgenic plants under abiotic stress condition. (A) GUS activities in 7-day-old seedlings under $300 \mathrm{mM} \mathrm{NaCl}$, low temperature $\left(4^{\circ} \mathrm{C}\right), 100 \mu \mathrm{M} \mathrm{ABA}$ or $10 \mu \mathrm{M}$ MV treatments for $5 \mathrm{hr}$. (B) Semi-quantitative RT-PCR analysis was performed using seedlings treated with $300 \mathrm{mM} \mathrm{NaCl}$. GAPc was used as an internal control. 
sue-specific expression binary vectors can be used for the gene expression in a place or time that the gene is not normally expressed. In addition, the simple overexpression of target gene driven by a strong promoter such as CaMV $35 \mathrm{~S}$ promoter sometimes prohibits plants from undergoing the normal growth and even causes death [27]. These hindrances can be overcome by tissue-specific or development-specific binary vectors constructed in this study.

In plants, a number of genes have been reported to be expressed in response to abiotic stresses such as drought, high salinity and low temperature. The promoter region of RD29A, typical abiotic stress marker gene, contains at least two types of cis-acting elements, two dehydration-responsive elements (DREs) and one ABA-responsive element (ABRE) which are involved in ABA-independent and ABA-responsive gene expression, respectively [31,32,35]. AtNCED3 is involved in an early step in controlling osmotic stress-induced ABA biosynthesis [34] and is induced by drought stress. AtNCED3-overexpressing transgenic plants showed improved drought tolerance [14].

Binary vectors were constructed and tested with abiotic stress-inducible promoters. With RD29A promoter, GUS expression in cotyledons was induced strongly by $\mathrm{NaCl}, \mathrm{ABA}$, MV and low temperature treatments (Fig. 4). With AtNCED3 promoter, GUS expression was induced moderately in cotyledons by $\mathrm{NaCl}, \mathrm{ABA}$ and $\mathrm{MV}$ treatments but was not induced by low temperature (Fig. 5). These stress-inducible binary vectors can be used to express target genes under conditions which the genes are not normally expressed. In some cases, simple overexpression of stress-related genes under normal condition wastes the energy of plants and hinders plant growth [27]. It is possible to generate transgenic plants expressing target genes only under stressful conditions using these stress-inducible binary vectors.

Our results showed that the magnitude of stress-inducibility of each vector was different, suggesting that each vector can be used to express target genes differently depending on the level of expression; binary vector with RD29A promoter showed strong induction but AtNCED3 promoter was moderate. Taken together, our binary vectors for stress-inducible expression may be suitable to engineer stress-tolerant transgenic plants by genetic modification.

In summary, various binary vectors using pPZP backbone for ectopic expression of target genes were constructed and they would be very useful to study the biological and molecular functions of target genes in plants.

\section{Acknowledgement}

This work was supported for two years by Pusan National University Research Grant.

\section{References}

1. An, G. 1986. Development of plant promoter expression vectors and their use for analysis of differential activity of nopaline synthase promoter in transformed tobacco tissue. Plant Physiol. 81, 86-91.

2. Bevan, M. 1984. Binary Agrobacterium vectors for plant transformation. Nucleic Acids Res. 12, 8711-8721.

3. Blázquez, M. A., C. Ferrándiz, F. Madueño, and F. Parcy. 2006. How floral meristems are built. Plant Mol. Biol. 60, 855-870.

4. Christensen, A. H., R. A. Sharrock, and P. H. Quail. 1992. Maize polyubiquitin genes: structure, thermal perturbation of expression and transcript splicing, and promoter activity following transfer to protoplasts by electroporation. Plant Mol. Biol. 18, 675-689.

5. Clough, S. J. and A. F. Bent. 1998. Floral dip: a simplified method for Agrobacterium-mediated transformation of Arabidopsis thaliana. Plant J. 16, 735-743.

6. Deblaere, R., A. Reynaerts, H. Hofte, J. P. Hernalsteens, J. Leemans, and M. Van Montagu. 1987. Vectors for cloning in plant cells. Meth. Enzymol. 153, 277-292.

7. Gallagher, S. R. 1992. GUS protocols: using the GUS gene as a reporter of gene expression. San Diego CA, USA: Academic Press Inc.

8. Gandhi, R., S. C. Maheshwari, and P. Khurana. 1999. Transient gene expression and influence on foreign gene expression in Arabidopsis thaliana. In Vitro Cell Dev. Biol. Plant 35, 232-237.

9. Garbarino, J. E., T. Oosumi, and W. R. Belknap. 1995. Isolation of a polyubiquitin promoter and its expression in transgenic potato plants. Plant Physiol. 109, 1371-1378.

10. Guerche, P., C. Tire, F. G. De Sa, A. De Clercq, M. Van Montagu, and E. Krebbers. 1990. Differential expression of the Arabidopsis 2S Albumin genes and the effect of increasing gene family size. Plant Cell 2, 469-478.

11. Hajdukiewicz, P., Z. Svab, and P. Maliga. 1994. The small, versatile $\mathrm{pPZP}$ family of Agrobacterium binary vectors for plant transformation. Plant Mol. Biol. 25, 989-994.

12. Hauke, H., M. C. Guitton, and R. Reski. 2002. Plant functional genomics. Naturwissenschaften 89, 235-249.

13. Holtorf, S., K. Apel, and H. Bohlmann. 1995. Comparison of different constitutive and inducible promoters for the overexpression of transgenes in Arabidopsis thaliana. Plant Mol. Biol. 29, 637-646.

14. Iuchi, S., M. Kobayashi, T. Taji, M. Naramoto, M. Seki, T. Kato, S. Tabata, Y. Kakubari, K. Yamaguchi-Shinozaki, and K. Shinozaki. 2001. Regulation of drought tolerance by gene manipulation of 9-cis-epoxycarotenoid dioxygenase, a key 
enzyme in abscisic acid biosynthesis in Arabidopsis. Plant J. 27, 325-333.

15. Jackson, D., B. Veit, and S. Hake. 1994. Expression of maize KNOTTED-1 related homeobox genes in the shoot apical meristem predicts patterns of morphogenesis in the vegetative shoot. Development 120, 405-413.

16. Kamo, K. K. 2003. Long-term expression of the uidA gene in Gladiolus plants under control of either the ubiquitin, rolD, mannopine synthase, or cauliflower mosaic virus promoters following three seasons of dormancy. Plant Cell Rep. 21, 797-803.

17. Lee, L. Y. and S. B. Gelvin. 2008. T-DNA binary vectors and systems. Plant Physiol. 146, 325-332.

18. Lee, Y. M., H. Y. Seok, H. Y. Park, J. I. Park, J. S. Han, T. S. Bang, and Y. H. Moon. 2009. Construction and verification of useful vectors for ectopic expression and suppression of plant genes. J. Life Sci. 19, 809-817.

19. Lincoln, C., J. Long, J. Vamaguchi, K. Serikawa, and S. Hake. 1994. A knottedl-like homeobox gene in Arabidopsis is expressed in the vegetative meristem and dramatically alters leaf morphology when overexpressed in transgenic plants. Plant Cell 6, 1859-1876.

20. Ma, B. L., K. D. Subedi, and L. M. Reid. 2004. Extent of Cross-Fertilization in Maize by Pollen from Neighboring Transgenic Hybrids. Crop Sci. 44, 1273-1282.

21. Murashige, T. and F. Skoog. 1962. A revised medium for rapid growth bioassays with tobacco tissue cultures. Plant Physiol. 15, 473-497.

22. Nakashima, K., Y. Fujita, K. Katsura, K. Maruyama, Y. Narusaka, M. Seki, K. Shinozaki, and K. YamaguchiShinozaki. 2006. Transcriptional regulation of ABI3- and ABA-responsive genes including RD29B and RD29A in seeds, germinating embryos, and seedlings of Arabidopsis. Plant Mol. Biol. 60, 51-68.

23. Norris, S. R., S. E. Meyer, and J. Callis. 1993. The intron of Arabidopsis thaliana polyubiquitin genes is conserved in location and is a quantitative determinant of chimeric gene expression. Plant Mol. Biol. 21, 895-906.

24. Okamuro, J. K. and R. B. Goldberg. 1989. Regulation of plant gene expression: General principles. In PK stumpf. The Biochemistry of Plants: Academic Press Inc.
25. Parcy, F., O. Nilsson, M. A. Busch, I. Lee, and D. Weigel. 1998. A genetic framework for floral patterning. Nature 395, 561-566.

26. Plesse, B., M. C. Criqui, A. Durr, Y. Parmentier, J. Fleck, and P. Genchik. 2001. Effects of the polyubiquitin gene Ubi.U4 leader intron and first ubiquitin monomer on reporter gene expression in Nicotiana tabacum. Plant Mol. Biol. 45, 655-667.

27. Sakuma, Y., K. Maruyama, Y. Osakabe, F. Qin, M. Seki, K. Shinozaki, and K. Yamaguchi-Shinozaki. 2006. Functional Analysis of an Arabidopsis Transcription Factor, DREB2A, Involved in Drought-Responsive Gene Expression. Plant Cell 18, 1292-1309.

28. Sánchez, R., M. Y. Kim, M. Calonje, Y. H. Moon, and Z. R. Sung. 2009. Temporal and spatial requirement of EMF1 activity for Arabidopsis vegetative and reproductive development. Mol. Plant 2, 643-653.

29. Schultz, E. A. and G. W. Haughn. 1991. LEAFY, a homeotic gene that regulates inflorescence development in Arabidopsis. Plant Cell 3, 771-781.

30. Sheen, J. 2001. Signal Transduction in Maize and Arabidopsis Mesophyll Protoplasts. Plant Physiol. 127, 1466-1475.

31. Shinozaki, K. and K. Yamaguchi-Shinozaki. 2006. Transcriptional regulation of ABI3- and ABA-responsive genes including RD29B and RD29A in seeds, germinating embryos, and seedlings of Arabidopsis. Plant Mol. Biol. 60, 51-68.

32. Thomashow, M. F. 1999. Plant cold acclimation: freezing tolerance genes and regulatory mechanisms. Annu. Rev. Plant Physiol. Plant Mol. Biol. 50, 571-599.

33. Weigel, D. and J. Glazebrook. 2006. Transformation of Agrobacterium using the freeze-thaw method. Cold Spring Harb. Protoc. 10, 1101.

34. Xiong, L., H. Lee, M. Ishitani, and J. K. Zhu. 2002. Regulation of osmotic stress-responsive gene expression by the LOS6/ABA1 locus in Arabidopsis. J. Biol. Chem. 277, 85888596.

35. Yamaguchi-Shinozaki, K. and K. Shinozaki. 1994. A novel cis-acting element in an Arabidopsis gene is involved in responsiveness to drought, low-temperature, or high-salinity stress. Plant Cell 6, 251-264. 


\section{초록 : 식물에서 표적 유전자의 동시 과발현, 조직/발달 특이적 발현 및 스트레스 유도성 발현을 위한 binary 벡터의 제작과 분석}

이영미 · 박희연 · 우동혁 · 석혜연 · 이선영 ${ }^{1} \cdot$ 문용환* $^{*}$

(부산대학교 분자생물학과, ${ }^{1}$ 울산대학교 의과대학 생의과학연구소)

유전자를 이소성으로 발현하고 억제하는 것은 유전자의 기능 연구에 있어서 매우 유용하다. 본 연구에서는 표 적 유전자의 동시 과발현, 조직/발달 단계 특이적 발현 및 스트레스 유도성 발현을 위해 pPZP를 골격으로 다양 한 binary 벡터를 제작하고 그 유용성을 검증하였다. 변형된 CaMV 355 프로모터를 이용하여, 다른 두 개의 유전 자를 동시 과발현시키는 binary 벡터를 제작하였고, 이 벡터가 동시에 그리고 같은 장소에서 다른 두 개의 표적 유전자를 과발현 하는데 효과적임을 확인하였다. At2S3, KNAT1 및 LFY 프로모터를 포함하는 조직 또는 발달 단계 특이적 발현 binary 벡터들을 제작하고 분석한 결과, 이 벡터들은 각각 배/유식물 시기, 새싹 끝의 분열조직 및 잎 원기 특이적 발현에 유용하였다. RD29A와 AtNCED3 프로모터를 포함하는 스트레스 유도성 발현 binary 벡터들은 고염, $\mathrm{ABA}, \mathrm{MV}$ 또는 저온과 같은 비생물성 스트레스에 의한 유전자의 이소성 발현에 유용하였다. 본 연구에서 제작된 binary 벡터들은 표적 유전자의 이소성 발현을 통해 유전자의 생물학적 기능연구, 분자생물학적 작용 기작 연구에 유용하게 사용될 것으로 사료된다. 